\title{
A Duration Analysis of CONALEP \\ (Mexico's National Technical Professional School)
}

Gladys López-Acevedo ${ }^{1}$

JEL Classification: I28; J24 and N36.

Key Words: Technical education, duration analysis.

World Bank Policy Research Working Paper 3327, June 2004

The Policy Research Working Paper Series disseminates the findings of work in progress to encourage the exchange of ideas about development issues. An objective of the series is to get the findings out quickly, even if the presentations are less than fully polished. The papers carry the names of the authors and should be cited accordingly. The findings, interpretations, and conclusions expressed in this paper are entirely those of the authors. They do not necessarily represent the view of the World Bank, its Executive Directors, or the countries they represent. Policy Research Working Papers are available online at http://econ.worldbank.org.

\footnotetext{
${ }^{1}$ Economist, World Bank, gacevedo@worldbank.org. This research was completed as part of the "Training Mechanisms Reform" Project at the World Bank. I am particularly grateful to Indermit S. Gill who provided valuable advice.
} 
Summary

Mexico's National Technical Professional School (CONALEP) is the largest technical education system in the country. CONALEP serves low-income students at the upper-secondary school level in Mexico. Using graduate tracer surveys from CONALEP, this paper analyzes the impact of modular courses and reform programs implemented by CONALEP in 1991-1992 on CONALEP graduates' labor market outcomes. Results indicate that graduates from the prereform program had to search longer for a job compared with those of the postreform program. Graduates from the post-reform program have 45 percent higher probability of finding a job than those from the pre-reformed program. However, the pre-reform program cohorts earned higher hourly wages than those from the post-reform program. 


\section{Introduction}

In December of 1978, the Mexican Government created the National Technical Professional School (Colegio Nacional de Educación Profesional Técnica, CONALEP) as a public decentralized body of the Ministry of Public Education (SEP). CONALEP was intended to provide a national network of upper-secondary schools that would prepare young people to become technicians at the upper-middle educational level. At skill level 4 in the International Standard Classification of Education (upper-secondary), there was a gap that was growing with the increasing demand for skilled labor. With the establishment of CONALEP, the Government also wanted to strengthen and rationalize the complex provision for technical secondary education in Mexico (OECD, 1997).

In 1979, the first 10 CONALEP schools were opened, offering training in seven professions to 4,100 students. Not surprisingly, five of these professional areas were in manufacturing, while the other two were medical assistant and nursing professions. By 1982 the number of students enrolled in courses in CONALEP leading to technical qualifications increased to 72,000 , and by $1989-1990$ the total was 155,300 . Since 1983 , in addition to its career programs for technicians, CONALEP has also offered short courses for industry. This program was expanded in 1986 through the introduction of mobile training facilities. By 1990, the number of students enrolled in these courses had increased to 61,300 (Carnoy and others, 2000).

The major growth in student numbers during this period was facilitated by rapid growth in the number of CONALEP schools, from 10 in 1979 to 239 in 1986, by which date all 31 states in Mexico had CONALEP schools. However, the distribution of students by state was uneven, with about one-third of all students attending schools within the metropolitan zone of Mexico City. The size of the individual CONALEP schools was also uneven. The number of professions expanded substantially from the original seven to 146 by the beginning of the 1990s, although they were reduced to 29 between 1993 and the beginning of 1997. The rapid growth during the 1980s and the beginning of the 1990s coincided with a shift toward white-collar occupations in commerce, administration, computing, and accounting, which now comprise more than half of the students in CONALEP. The educational services at CONALEP schools were expanded in 
1991-1992 by the introduction of the modular program, which was the forerunner of competency-based education and training (CBET) (Hobart, 1999).

In 1998, as part of the Education Modernization Project (PMETyC), CONALEP introduced CBET for nine areas of training, to bring the CONALEP education program closer to the needs of industry. The initial pilot project to introduce competency-based education and training effectively in CONALEP demonstrated the challenges of this new way of teaching. This project helped the institution to understand the complexities of its significant role as a player in the forthcoming standards-based approach to education and training, and the need for major reforms to its administration and educational practices (CONALEP, 1994 and 1999).

This paper attempts to analyze the impact of modular courses implemented by CONALEP in 1991-1992 on CONALEP graduates' labor market outcomes. The intention of the paper is to answer the following four questions: 1) Did the graduates from the 1998 reform program find jobs faster than those from the cohorts of the 1994 survey from the pre-reform program? 2) Did the reformed program increase graduate probability of continuing their education after completing CONALEP? 3) Did the reformed program give CONALEP graduates more status in the job market? 4) Did the reforms of the CONALEP program increase the earnings that it graduates received?

This paper is organized as follows: Section two presents a description of CONALEP's students and graduates. Section three discusses CONALEP's past evaluations. Section four introduces the CONALEP graduate tracer surveys used in this paper. Section five describes the methodology used in this paper. Section six presents the results of the duration analysis of CONALEP. Finally, section seven offers conclusions.

\section{The Evaluation of the CONALEP System: Students and Graduates}

The socioeconomic and academic level of CONALEP students varies according to location. Data from the National Evaluation Center (Centro Nacional de Evaluación, CENEVAL) suggest that CONALEP most frequently serves low-income students at the uppersecondary school level in Mexico City. The results of a random sample of those who took the entrance examination to upper-secondary school in the metropolitan area of Mexico City in 1999 suggest that CONALEP students come from families with the lowest average income and the lowest parental education (Table 1). The parents of an average CONALEP student have about 
two years less formal education than the parents of a student attending an upper secondary school (Colegio de Bachilleres), and three years less formal education than the parents of a student attending the high schools of the National Polytechnic Institute.

Table 1 CONALEP Students Compared to Students from Selected Institutions ${ }^{2}$ Centro Nacional de Evaluación

\begin{tabular}{|c|c|c|c|c|c|c|c|}
\hline $\begin{array}{c}\text { All } \\
\text { Institutions }\end{array}$ & $\begin{array}{l}\text { Option }^{1} \\
\text { Number }\end{array}$ & $\begin{array}{c}\text { Global }^{2} \\
\text { Test Score }\end{array}$ & $\begin{array}{l}\text { Family }^{3} \\
\text { Income }\end{array}$ & $\begin{array}{c}\text { GPA in } \\
\text { Lower- } \\
\text { secondary }\end{array}$ & $\begin{array}{l}\text { Mother's } \\
\text { Schooling } \\
\text { (years) }\end{array}$ & $\begin{array}{c}\text { Father's } \\
\text { Schooling } \\
\text { (years) }\end{array}$ & $\begin{array}{c}\text { Private Lower } \\
\text { Sec }=1\end{array}$ \\
\hline \multicolumn{8}{|l|}{ CONALEP } \\
\hline Mean & 2.27 & 54.2 & 2271.2 & 7.627 & 7.1 & 8.2 & 8.70E-03 \\
\hline $\mathrm{N}$ & 460 & 460 & 460 & 460 & 460 & 460 & 460 \\
\hline $\mathrm{SD}$ & 2.13 & 15.3 & 2269 & 6992 & 4.8 & 5.2 & $9.29 \mathrm{E}-02$ \\
\hline \multicolumn{8}{|l|}{ Colegio de } \\
\hline Bachilleres & 3.05 & 66.4 & 3132 & 7.658 & 9.0 & 10.0 & 3.33E-02 \\
\hline \multicolumn{8}{|l|}{ Mean } \\
\hline $\mathrm{N}$ & 421 & 421 & 421 & 421 & 421 & 421 & 421 \\
\hline $\mathrm{SD}$ & 2.28 & 13.2 & 2845 & .75722 & 5.2 & 5.1 & .18 \\
\hline \multicolumn{8}{|c|}{ Estado de México } \\
\hline Mean & 2.41 & 64.6 & 2721 & 7.931 & 8.452 & 9.9 & $1.76 \mathrm{E}-02$ \\
\hline $\mathrm{N}$ & 1192 & 1192 & 1192 & 1192 & 1192 & 1192 & 1192 \\
\hline SD & 2.09 & 16.56 & 2436 & .7600 & 4.9 & 5.2 & .13 \\
\hline \multicolumn{8}{|l|}{ DGETI } \\
\hline Mean & 2.71 & 59.6 & 2610 & 7.7205 & 7.700 & 9.2 & $2.20 \mathrm{E}-02$ \\
\hline $\mathrm{N}$ & 682 & 682 & 682 & 682 & 682 & 682 & 682 \\
\hline $\mathrm{SD}$ & 2.32 & 15.6 & 2488 & .7271 & 5.0 & 5.4 & .15 \\
\hline \multicolumn{8}{|l|}{ IPN } \\
\hline Mean & 1.97 & 80.7 & 3315 & 8.1865 & 9.8 & 11.3 & $5.81 \mathrm{E}-02$ \\
\hline $\mathrm{N}$ & 430 & 430 & 430 & 430 & 430 & 430 & 430 \\
\hline SD & 1.61 & 13.9 & 2552 & .7871 & 4.7 & 5.0 & .23 \\
\hline \multicolumn{8}{|l|}{ UNAM } \\
\hline Mean & 1.46 & 88.1 & 3967 & 8.3935 & 9.8 & 11.4 & $9.41 \mathrm{E}-02$ \\
\hline $\mathrm{N}$ & 510 & 510 & 510 & 510 & 510 & 510 & 510 \\
\hline SD & .83 & 11.6 & 3385 & .7864 & 5.212 & 5.0 & .29 \\
\hline \multicolumn{8}{|l|}{ Other } \\
\hline Mean & 1.38 & 82.9 & 3896 & 8.5417 & 11.969 & 12.9 & 8.33E-02 \\
\hline $\mathrm{N}$ & 48 & 48 & 48 & 48 & 48 & 48 & 48 \\
\hline SD & .96 & 15.8 & 3164 & .8124 & 3.676 & 4.2 & .28 \\
\hline \multicolumn{8}{|l|}{ TOTAL } \\
\hline Mean & 2.33 & 67.9 & 2945 & 7.9248 & 8.6 & 10.0 & $3.50 \mathrm{E}-02$ \\
\hline $\mathrm{N}$ & 3743 & 3743 & 3743 & 3743 & 3743 & 3743 & 3743 \\
\hline SD & 2.03 & 18.5 & 2693 & .7982 & 5.1 & 5.2 & .18 \\
\hline
\end{tabular}

Students attending CONALEP do not necessarily do poorly on the entrance test, nor do they all come from low educated or low-income parents. About $20 \%$ of CONALEP students in this sample scored higher than the average student attending the Colegio de Bachilleres.

\footnotetext{
${ }^{2}$ Colegio de Bachilleres is the local answer to over-demand; Estado de México is a state-centralized high school system; DGETI is the Dirección General de Educación Técnica Profesional, a centralized institution; IPN is the Instituto Politécnico Nacional -centralized; and UNAM is the Universidad Nacional Autónoma de México autonomous.
} 
Approximately 35 to $40 \%$ of the parents of CONALEP students have higher levels of education than the parents of an average student at the Colegio de Bachilleres. Nonetheless, on average, CONALEP students come from the lower socioeconomic categories and generally have lower scores in the CENEVAL examination than students in the other streams of uppersecondary education. Only students attending other technical-professional schools (DGETI) are comparably low on these indicators.

\section{CONALEP's Past Evaluations}

The CONALEP system as a whole has been evaluated several times in the past. The first evaluation was done by CONALEP (1994) and CONALEP (1999) using graduate tracer surveys. These data sets are described in the next section. The other evaluations were done by Lane and Tan (1996) and by Lee (1998). CONALEP also hired international consultants (Carnoy and others 2000) to assess the evolution of the CONALEP system. For this purpose the consultants used a different data set, as is explained below.

The CONALEP 1994 and 1999 tracer studies had several problems, one of the most important being the lack of a well defined control group. A control group was expected to be added later, using data from the National Urban Employment Survey (ENEU). However, the studies neither include in-depth information on how the analysis was performed nor provide useful information on how CONALEP graduates perform relative to a control group.

Lane and Tan (1996) also encountered several problems in their evaluation. The first was the construction of a non-arbitrary control group. The ENEU sample is representative of metropolitan areas while the CONALEP graduate tracer survey is representative nationally. The difference in geographical coverage of the two groups makes comparison difficult. Second, the control groups were constructed ad hoc. The control groups included individuals between the ages of 17 and 30: (A) those who have completed lower-secondary education; (B) those who have completed non-professional, elementary vocational training (CECATI), and (C) those who have completed one to three years of general academic (non-vocational) high school. Some doubts remain with respect to the second group, since the ENEU survey does not distinguish between formal and informal training/technical courses.

Lee (1998) compares the individuals from the Encuesta de Egresados 1994 (the treatment group) with two other groups. One group comprises all 1991 graduates from upper-secondary 
diversified technical education programs; this group's labor force participation and employment performance in January 1994 was compared with that of CONALEP graduates of 1991, and of 1991-93 combined. The first comparison group was created from a mail survey of all graduates, with a $45 \%$ response rate, and therefore is likely to be biased toward those who were either employed, studying, or had a higher level of earnings. The second comparison group was made up of employed workers aged 20 to 24, as reported in the aggregates of the ENEU of January 1994.

The results of these evaluations concluded that CONALEP graduates actively participated in the labor market at a much higher rate than the similar age cohort of the general population, and at a much higher rate than graduates from traditional technical high schools. On average, CONALEP graduates found jobs faster than control individuals, and about two-thirds of CONALEP graduates worked in jobs related to the specialization they had studied. Using crosscohort comparison, these evaluations also suggested that CONALEP graduates' earnings increased rapidly within the first two to three years of employment.

These conclusions are as expected, although the magnitudes of the participation rate and the increase in earnings in comparison to the magnitudes in traditional technical high schools and the general population are surprising-30\% in Lane and Tan, and $40 \%$ in Lee. The results should be considered with caution, since these studies failed to control for possible self-selection bias that could account for different labor market outcomes between the CONALEP group and the comparison groups. In addition, some of these evaluations do not fully explain how the control groups were constructed.

A fourth evaluation, aimed at understanding the background experience and goals of CONALEP students, conducted a survey with $5 \%$ of the senior students (ready to graduate) and freshmen students, the control group. The sample was 4,930 third year students and 725 first year students who, on the basis of their responses, were then divided into three groups using a socioeconomic status indicator. The results confirm the assumption that close to one-third of the students from CONALEP come from a low socioeconomic background. Another $40 \%$ come from a middle socioeconomic range. About $18 \%$ have parents with basic secondary school or more, own their own home with four or more rooms and have either a car, a phone, or both. The average entry test scores for the sample show several important trends in social class, gender, and cohort, as described below. 
Girls in both cohorts enter CONALEP with slightly lower scores than boys. The first year (1999) cohort entered with higher scores than the third year (1997) cohort. Thus, we could conclude that CONALEP student entry scores have actually risen more than suggested by the data. In the third-year cohort, entry scores positively correlated with rising socioeconomic indicators for both boys and girls. However, there seems to be little relationship between socioeconomic status and entry score in the 1999 cohort, except for higher-class girls.

In sum, CONALEP students tend to come from relatively low socioeconomic backgrounds and tend to score at the lower passing end of the higher secondary school entry test. About half have general basic secondary education, with another third coming from basic technical secondary schools. Somewhat less than half of the third year students indicate that the CONALEP option was their first choice of higher secondary school, and somewhat more than half of the first year cohort say it was their first choice.

A second questionnaire was given to firms that hired CONALEP graduates from regular courses or training courses. In general, the interviewed firms who hire students from CONALEP and use its training services think highly of the organization. Approximately $72 \%$ of firms (public lower, private higher) think that the academic level attained by CONALEP students is high or very high. About 55 to $60 \%$ of companies said that the technological level of a CONALEP education is high or very high, with large public companies giving the lowest ranking $(46 \%)$.

Using matched pair methods, Lopez-Acevedo (2002) re-evaluates the labor market performance of CONALEP graduates. She shows that individuals in the control group find jobs faster than CONALEP graduates do, but a higher proportion of the CONALEP graduates work in the occupational category congruent with their field of specialization or training. CONALEP graduates earn between 20 to 28 percent higher wages than the control group. The results indicate that employers invest more in training CONALEP graduates than they invest in the control group.

\section{Data: The CONALEP Graduate Tracer Surveys}

The first CONALEP graduate tracer survey was conducted in February 1994 (CONALEP, 1994) on the basis of a random sample of 1,500 former CONALEP students who graduated between June 1991 and June 1993. The surveyed graduates were selected to represent 
the profile of the graduates in each of the three years in terms of all 13 major occupational groups of careers and the six geographical regions of the country. However, the sample is dominated by 1992 graduates who comprise 50\% of the sample; 1991 and 1993 graduates each represent $25 \%$ (Tables 2 and 3 ). The sample selection is probabilistic and statistically representative of the universe of graduates in each cohort. For each graduate, three substitutes were chosen from the same career and school.

Table 2 Distribution of the 1994 Sample by Cohort

\begin{tabular}{ccccc}
\hline $\begin{array}{c}\text { Graduation Year } \\
\text { Cohort }\end{array}$ & $\begin{array}{c}\text { Planned } \\
\text { Selection }\end{array}$ & $\mathbf{\%}$ & $\begin{array}{c}\text { Actual } \\
\text { Selection }\end{array}$ & $\mathbf{\%}$ \\
\hline 1991 & 375 & 25 & 346 & 24.7 \\
1992 & 750 & 50 & 704 & 50.3 \\
1993 & 375 & 25 & 349 & 24.9 \\
Total & 1500 & 100 & 1399 & 100 \\
\hline
\end{tabular}

Source: CONALEP (1994).

Table 3 Actual Sample Selection (original and substitutes by cohort)

\begin{tabular}{ccccccc}
\hline & Selected & \multicolumn{3}{c}{ Substitutes } & Total & \% vs. 1,500 \\
\hline Graduation Year Cohort & & $1^{\text {st }}$ & $2^{\text {nd }}$ & $3^{\text {rd }}$ & 346 & 23.1 \\
1991 & 268 & 53 & 20 & 5 & 704 & 49.9 \\
1992 & 560 & 96 & 42 & 6 & 349 & 23.3 \\
1993 & 286 & 46 & 15 & 2 & 1,399 & 93.3 \\
Total & 1,114 & 195 & 77 & 13 & & \\
Cumulative percentage & $74.3 \%$ & $87.3 \%$ & $92.4 \%$ & $93.3 \%$ & $93.3 \%$ & \\
\hline
\end{tabular}

Source: CONALEP (1999).

The second CONALEP Graduate Tracer Study (CONALEP 1999) was conducted between May and June of 1998 on the basis of a random sample of individuals who graduated between June 1993 and June 1997. The sample is representative of geographical regions, all 29 careers and all cohorts. The difference between the actual sample of 5,574 individuals and the planned sample of 10,000 was due to exogenous factors such as changes in address $(3,590$ cases); addresses that belonged to different states (651 cases); differences between the number of graduates officially registered and those found in the administrative records (229 cases), and technical careers that had never been offered (7 cases). CONALEP (1998) extensively reviews the sample frame of the second CONALEP Graduate Survey as described by LEVANTA, the 
consultant firm which designed the sample process. The distribution of the 1998 CONALEP survey was as follows. Table 4 shows that the response rate is high.

Table 4 Distribution of the 1998 Sample by Cohort

\begin{tabular}{cccc}
\hline Cohort & $\begin{array}{c}\text { Interviewed Graduates } \\
\text { Number }\end{array}$ & $\begin{array}{c}\text { \% Completed } \\
\text { Interviews }\end{array}$ \\
\hline $90-93$ & 779 & 14.0 & 59.0 \\
$91-94$ & 951 & 17.1 & 72.0 \\
$92-95$ & 1,127 & 20.2 & 85.4 \\
$93-96$ & 1,268 & 22.7 & 96.1 \\
$94-97$ & 1,449 & 26.0 & $109.8^{3}$ \\
Total & 5,574 & 100.0 & 84.5 \\
\hline
\end{tabular}

Source: LEVANTA C.

\section{Methodology}

Given that the CONALEP graduate tracer surveys of 1994 and 1998 are comparable, this paper analyzes the impact of modular courses implemented by CONALEP after 1992. The cohorts from the survey of 1994 are considered to be graduates of the pre-reform program including cohorts who graduated in 1991, 1992, and 1993. Additionally, cohorts from the survey of 1998 are considered to be from the post-reform program including cohorts who graduated in 1994, 1995, 1996, and 1997.

The Kaplan-Meier and the proportional hazard models were calculated to analyze whether graduates from the cohorts of the 1998 survey of the reformed program found a job faster than those from the cohorts of the 1994 survey of the pre-reform program. The variable of interest in this duration analysis is the length of time to find a job after graduating from CONALEP, conditional on being unemployed or searching for a job. The functions of interest are the survival and hazard functions:

$$
\begin{aligned}
& \text { Survival function: } P\{T \geq t\} \\
& \text { Hazard rate: } \lambda(t)=\lim _{\Delta \rightarrow \infty} \frac{P\{t \leq T \leq t+\Delta \mid T \geq t\}}{\Delta},
\end{aligned}
$$

\footnotetext{
3 This value, as listed in CONALEP data sets, appears to exceed $100 \%$ because the number of responding graduates
} exceeded the goal number. 
Kaplan-Meier is a strictly empirical approach (non-parametric), but it does not consider the influence of covariates. The estimators are given by:

$$
\begin{aligned}
& \hat{S}\left(T_{k}\right)=\prod_{i=1}^{k} \frac{n_{i}-d_{i}}{n_{i}} \\
& \hat{\lambda}\left(T_{k}\right)=\frac{d_{i}}{n_{i}},
\end{aligned}
$$

where: $n_{k}$ is the number of individuals whose observed duration is at least $T_{k}$, and $d_{k}$ is the number of observed drop-outs at time $T_{k}$.

The Cox model allows exploration of the relationship between the survival experience of an individual and a set of explanatory variables or covariates. In the present analysis, the hazard rate is the risk to find a job after being unemployed. The model specifies that the hazard is given by:

$$
\lambda\left(t_{i}\right)=e^{\beta^{\prime} \mathbf{X}_{i}} \lambda_{0}(t)
$$

where: $\lambda_{0}(t)$ is the baseline hazard, or the hazard for an individual with $\mathbf{X}=\mathbf{0}$.

$\mathbf{X}_{i}$ is the vector of explanatory variables for individual $i$.

$\mathbf{X}_{i}$ includes variables such age, gender, schooling, region, gross domestic product (GDP).

The parameter estimates, $\hat{\beta}$; are obtained maximizing the partial likelihood.

The estimated survival function for the individual $i$ is:

$$
\hat{S}_{i}(t)=\left[\hat{S}_{0}(t)\right]^{\exp \left(\hat{\boldsymbol{\beta}}^{\prime} \mathbf{x}_{i}\right)}
$$

where: $\hat{S}_{0}(t)$ is the estimated baseline survival function (for an individual with $\mathbf{X}=\mathbf{0}$ ).

The Cox regression model is semi-parametric because no particular probability distribution is assumed for the survival times, although the model is based on the assumption of proportional hazards. The adequacy of the fitted model was also tested throughout the residuals. Residuals were calculated for each individual in the sample. Their behavior is approximately known when the fitted model is satisfactory. A number of residuals have been proposed, among them the martingale residuals, which take values between $-\infty$ and 1 ; they have properties similar 
to those of linear regression, but they are not symmetrically distributed around zero. Another method that was used to verify the assumption of proportional hazards between the groups of interest was the Kaplan-Meier estimate of the survival function for each group. For this estimate, we plotted $\log \left(\hat{\lambda}\left(t_{i}\right)\right)$ against $\log \left(t_{i}\right)$ which yielded parallel curves across the different groups, thereby providing evidence that the assumption of proportional hazard was correct.

Multinomial models were estimated to assess if the reformed program increased individuals' probability of studying further after completing CONALEP. They also permitted estimation of the probability of having a certain status in the job market. The multinomial models estimated have a response variable with categorical outcomes $0,1,2, \ldots, \mathrm{J}$. In this analysis, these variables are status in the labor market and the type of occupation. The model also has $\mathrm{K}$ explanatory variables, $\mathrm{X}_{i}=\left[x_{i 1}, x_{i 2}, \ldots, x_{i K}\right]$ such as age, region, schooling, gender, cohort, and $\mathrm{GDP}^{4}$. There are $\mathrm{K}$ parameters of the model for the outcome $\mathrm{j}, \mathrm{B}^{(j)}=\left[\beta_{1}^{(j)}, \beta_{2}^{(j)}, \ldots, \beta_{K}^{(j)}\right]$. In the multinomial logit model, the set of coefficients $\mathrm{B}^{(0)}, \mathrm{B}^{(1)}, \ldots \mathrm{B}^{(J)}$ corresponding to each outcome category is estimated. Assuming that $\mathrm{B}^{(0)}=\mathbf{0}$, where $y=0$ is the category base, the probability that the variable $y$ takes the value " $\mathrm{j}$ " is:

$$
\begin{gathered}
P_{i}^{(0)}=P_{i}\{y=0\}=\frac{1}{1+\sum_{j=1}^{J} e^{\mathrm{X}_{i} \mathrm{~B}^{(j)}}} \\
P_{i}^{(j)}=P_{i}\{y=j\}=\frac{e^{\mathrm{X}_{i} \mathrm{~B}^{(j)}}}{1+\sum_{j=1}^{J} e^{\mathrm{X}_{i} \mathrm{~B}^{(j)}}}, \quad \mathrm{j}=1,2, \ldots, \mathrm{J}
\end{gathered}
$$

The above-estimated equations provide a set of probabilities for the $\mathrm{J}+1$ choices faced by an individual with characteristics $X_{i}$. The marginal effects of the characteristics on the probabilities are obtained by differentiating (6):

$$
M E_{k}^{(j)}=\frac{\partial P^{(j)}}{\partial X_{k}}=P^{(j)}\left[\beta_{k}^{(j)}-\sum_{j=0}^{J} P^{(j)} \beta_{k}^{(j)}\right]
$$

\footnotetext{
${ }^{4}$ There is a question about whether the changes that are observed can be attributed to the change in the program rather than the external factors such as the state of the economy. For this reason, in the Kaplan-Meier and Cox models, we include control variables, such as GDP. Also, the reform period is not a recession or crisis period.
} 
The marginal effect for a categorical explanatory variable $\mathrm{k}$ can be estimated by:

$$
M E_{k}^{(j)}=\frac{\sum_{i=1}^{n} M E_{i k}^{(j)}}{n},
$$

where:

$$
M E_{i k}^{(j)}=P_{i}\left\{y=j \mid \mathrm{X}_{i} \text { with } x_{i k}=1\right\}-P_{i}\left\{y=j \mid \mathrm{X}_{i} \text { with } x_{i k}=0\right\} .
$$

Hypotheses about coefficients were tested using a likelihood ratio test, which is based on the statistic: $\chi_{c}^{2}=-2\left(L_{a}-L_{o}\right)$, which under Ho has the distribution $\chi_{\left(d_{0}-d_{a}\right)}^{2}$, where:

$L_{o}$ is the log-likelihood associated with the null hypothesis (constrained model).

$L_{a}$ is the log-likelihood associated with the alternative hypothesis (full model).

$d_{o}$ is the number of degrees of freedom for the constrained model.

$d_{a}$ is the number of degrees of freedom for the full model.

Finally, standard regression models were estimated to assess if the reformed CONALEP program increases CONALEP graduates' earnings .

\section{Results}

Table 5 shows the Kaplan-Meier estimates of the mean and median time of job search after graduation. The median time for cohorts graduating before the reforms were introduced in CONALEP (Survey 94) is 4 months, while for those cohorts in the reformed program (Survey 98) the median time is 3 months. The preliminary finding based on the Kaplan-Meier estimates is important because it shows that graduates from the 1998 Survey found jobs faster than those from the 1994 Survey. If only a simple average of values for surveyed individuals had been taken, the erroneous conclusion would be reached that graduates of the 1998 Survey search for a job longer than individuals of the 1994 Survey do. 
Table 5. Kaplan-Meier Estimates Job Search after graduation from CONALEP (Months)

Time Estimated

\begin{tabular}{ccc} 
Probability $\{T>t\}$ & Survey 94 & Survey 98 \\
\cline { 2 - 3 } 0.25 & 12.0 & 7.0 \\
0.5 & 4.0 & 3.0 \\
0.75 & 1.6 & 1.0 \\
& & \\
Mean & 9.2 & 6.8 \\
Median & 4.0 & 3.0 \\
& & \\
Cases censored & $169(20.4 \%)$ & $124(3.8 \%)$ \\
Total number of cases & 827 & 3273 \\
\hline
\end{tabular}

Table A1.1 shows the hazard ratio or risk of finding a job in a respondent's region. Graduates from the 98 Survey have a 45 percent greater probability of finding a job than graduates from the 94 Survey do. Graduates from the northern or central regions of Mexico have a higher probability of finding a job (between 60 and 45 percent) than graduates from the South (22 percent) do. The 1993-1996 cohort had a 4 percent higher probability of finding a job than the other cohorts did. Also, the higher the level of schooling of the household head, the higher the chance the CONALEP graduate had of finding a job.

In Table 6, various scenarios were calculated. Given a base category (male, living in the central region, age, and so on.), the median time for a male graduate to find a job in the 94 Survey is 4 months, and in the 98 Survey -2.8 months. The mean length of time that female graduates search for a job is longer than that for male graduates. Furthermore, female graduates in the 98 Survey found jobs faster than those from the 94 Survey did. Not surprisingly, the job search is longer for graduates who did not have any job experience while studying. However, the difference in job search time between individuals with work experience and those without is small.

Given the above base category, 18 percent more of 98 Survey respondents than those in the 94 Survey were working (see Table 7). In the 94 Survey, the North, Center, and Pacific regions correlate with an increased probability of working. The probability of searching for a job is 17 percent higher for the 1994 graduates than it is for the 1998 graduates. For 1994 female 
Table 6. Cox Regression Model. Job Search (time) after finishing CONALEP

\begin{tabular}{|c|c|c|c|}
\hline Covariate** & Survey 94 & Survey 98 & Difference \\
\hline Male & 4.0 & 2.8 & 1.2 \\
\hline Female & 4.9 & 3.0 & 1.9 \\
\hline Age (mean $=21.5$ years $)$ & 4.0 & 2.8 & 1.2 \\
\hline Age (22.5 years) & 4.0 & 2.8 & 1.2 \\
\hline Center Area & 4.0 & 2.8 & 1.2 \\
\hline South-East Area & 2.9 & 1.9 & 1.0 \\
\hline Center-South Area & 2.9 & 1.9 & 1.0 \\
\hline North-East Area & 2.0 & 1.9 & 0.1 \\
\hline North-West Area & 2.8 & 1.9 & 0.9 \\
\hline Center-North Area & 2.8 & 1.9 & 0.9 \\
\hline Pacific Area & 2.8 & 1.9 & 0.9 \\
\hline 91 Cohort & 4.0 & & \\
\hline 92 Cohort & 4.0 & & \\
\hline 93 Cohort & 5.0 & & \\
\hline 94 Cohort & & 4.9 & \\
\hline 96 Cohort & & 2.8 & \\
\hline 97 Cohort & & 2.9 & \\
\hline None - Primary HH & 4.0 & 2.8 & 1.2 \\
\hline Lower-Secondary HH & 4.0 & 2.8 & 1.2 \\
\hline Upper-Secondary HH & 4.0 & 2.8 & 1.2 \\
\hline University - + HH & 4.0 & 2.0 & 2.0 \\
\hline Don't know HH & 4.0 & 2.0 & 2.0 \\
\hline GDP per capita $($ mean=38.8) & 4.0 & 2.8 & 1.2 \\
\hline GDP per capita & 3.0 & 2.0 & 1.0 \\
\hline Worked when studying & 4.0 & 2.8 & 1.2 \\
\hline Did not work when studying & 5.0 & 3.0 & 2.0 \\
\hline
\end{tabular}

graduates, the probability of working is 16 percent higher than for females in 1998. Also, the probability of searching for a job is slightly higher for the 1994 graduates than it is for 1998 graduates. The probability that a graduate continues to study is three percent higher in the 1994 than in 1998 Survey. For female graduates the probability of working at home as homemakers is 16 percent higher in the 98 cohort (Table 7). Controlling for relevant variables, we found that the 94 Survey respondents earn higher hourly wages than the 1998 cohorts do (Tables A1.3). 
Table 7. Marginal Effects of Having a Certain Type of Activity after Completing CONALEP

\begin{tabular}{|c|c|c|c|c|c|c|c|}
\hline \multirow{2}{*}{ Variable } & \multicolumn{2}{|c|}{$\operatorname{Prob}[$ Activity $=j \mid X, d u m m y=k]$} & \multirow{2}{*}{$\begin{array}{c}\text { Marginal } \\
\text { Effect }\end{array}$} & \multirow[b]{2}{*}{ Variable } & \multicolumn{2}{|c|}{$\operatorname{Prob}[$ Activity $=j \mid X$, dummy $=k]$} & \multirow{2}{*}{$\begin{array}{c}\text { Marginal } \\
\text { Effect }\end{array}$} \\
\hline & $\begin{array}{c}\mathbf{k}=1 \\
\text { Survey } 98\end{array}$ & $\begin{array}{c}\text { k=0 } \\
\text { Survey } 94\end{array}$ & & & $\begin{array}{c}k=1 \\
\text { Survey } 98\end{array}$ & $\begin{array}{c}\text { k=0 } \\
\text { Survey } 94\end{array}$ & \\
\hline $\bar{j}=$ Work & & & & $j=$ Searching for job & & & \\
\hline Women & 0.64 & 0.80 & -0.162 & Women & 0.10 & 0.11 & -0.012 \\
\hline Age & & & 0.004 & Age & & & 0.000 \\
\hline South-East Area & 0.78 & 0.74 & 0.040 & South-East Area & 0.09 & 0.11 & -0.027 \\
\hline North-West Area & 0.82 & 0.73 & 0.085 & North-West Area & 0.06 & 0.12 & -0.055 \\
\hline Center-North Area & 0.84 & 0.73 & 0.111 & Center-North Area & 0.06 & 0.12 & -0.055 \\
\hline Pacific Area & 0.84 & 0.73 & 0.116 & Pacific Area & 0.04 & 0.12 & -0.081 \\
\hline 92 Cohort & & 0.75 & & 92 Cohort & & 0.10 & \\
\hline 93 Cohort & & 0.76 & & 93 Cohort & & 0.09 & \\
\hline Upper-secondary HH & 0.68 & 0.75 & -0.069 & Upper-secondary $\mathrm{HH}$ & 0.11 & 0.11 & 0.001 \\
\hline University - + HH & 0.73 & 0.75 & -0.012 & University - + HH & 0.08 & 0.11 & -0.035 \\
\hline Do not know HH & 0.74 & 0.75 & -0.003 & Do not know HH & 0.09 & 0.11 & -0.021 \\
\hline GDP per capita & & & 0.062 & GDP per capita & & & -0.057 \\
\hline
\end{tabular}

Base categories for independent variables: 94 Survey, men, Center area (D.F. and Mexico), 91 cohort, none or primary school education of household head (HH).

Units for GDP thousands of 1998 pesos. 
Table 7. (cont.)

\begin{tabular}{|c|c|c|c|c|c|c|c|}
\hline \multirow{2}{*}{ Variable } & \multicolumn{2}{|c|}{$\operatorname{Prob}[$ Activity $=j \mid X$, dummy $=k]$} & \multirow{2}{*}{$\begin{array}{c}\text { Marginal } \\
\text { Effect }\end{array}$} & \multirow[b]{2}{*}{ Variable } & \multicolumn{2}{|c|}{$\operatorname{Prob}[$ Activity $=j \mid X, d u m m y=k]$} & \multirow{2}{*}{$\begin{array}{c}\text { Marginal } \\
\text { Effect }\end{array}$} \\
\hline & $\begin{array}{c}\text { k=1 } \\
\text { Survey } 98\end{array}$ & $\begin{array}{c}k=0 \\
\text { Survey } 94\end{array}$ & & & $\begin{array}{c}k=1 \\
\text { Survey } 98\end{array}$ & $\begin{array}{c}\text { k=0 } \\
\text { Survey } 94\end{array}$ & \\
\hline $\bar{j}=$ Student & & & & $j=$ Housework & & & \\
\hline Women & 0.07 & 0.06 & 0.003 & Women & 0.17 & 0.01 & 0.160 \\
\hline Age & & & -0.005 & Age & & & 0.001 \\
\hline South-East Area & 0.06 & 0.06 & 0.000 & South-East Area & 0.06 & 0.07 & -0.009 \\
\hline North-East Area & 0.03 & 0.07 & -0.040 & North-East Area & 0.03 & 0.07 & -0.040 \\
\hline North-West Area & 0.04 & 0.07 & -0.029 & North-West Area & 0.06 & 0.07 & -0.005 \\
\hline Center-North Area & 0.04 & 0.07 & -0.033 & Center-North Area & 0.05 & 0.07 & -0.025 \\
\hline Pacific Area & 0.05 & 0.07 & -0.014 & Pacific Area & 0.05 & 0.07 & -0.023 \\
\hline 92 Cohort & & 0.07 & & 92 Cohort & & 0.07 & \\
\hline 93 Cohort & & 0.06 & & 93 Cohort & & 0.07 & \\
\hline Upper-secondary HH & 0.12 & 0.06 & 0.063 & Upper-secondary HH & 0.07 & 0.07 & 0.003 \\
\hline University - + HH & 0.13 & 0.06 & 0.063 & University - + HH & 0.05 & 0.07 & -0.020 \\
\hline Do not know HH & 0.04 & 0.06 & -0.028 & Do not know HH & 0.11 & 0.07 & 0.041 \\
\hline GDP per capita & & & -0.016 & GDP per capita & & & 0.014 \\
\hline
\end{tabular}

Units for GDP thousands of 1998 pesos. 


\section{Conclusions}

The Mexican government introduced CONALEP as an alternative to traditional uppersecondary education in the form of a technical education system. A major transformation of CONALEP took place in 1991, when it reduced the number of courses of study offered from 146 to 29 and introduced modular courses, the forerunner of the competency based education and training model (CBET) now adopted in Mexico.

This paper evaluates the benefits of the introduction of modular courses by examining graduates from before and after the reforms. Results indicate that graduates from the pre-reform program (1994 Survey) had to search longer for a job compared with those of the post-reform program (1998 Survey). Moreover, graduates from the post-reform program have 45 percent higher probability of finding a job than those from the pre-reform program. However, the 1994 Survey cohorts earned higher hourly earnings than the 1998 Survey cohorts. A plausible explanation is that since 1994, real wages have decreased in Mexico by almost 40 percent. 


\section{Selected References}

Carnoy, B., and others. 2000. Aprendiendo a trabajar: Una revisión del Colegio Nacional de Educación Profesional Técnica y del Sistema de Universidades Tecnológicas de México. Processed.

CONALEP (Colegio Nacional de Educación Profesional Técnica). 1994. Encuesta de Empleo a Egresados del CONALEP, Cohorts 1991, 1992 and 1993. Final Report.

-1999. Encuesta de Empleo a Egresados del CONALEP, Cohorts 1991, 1992, 1993, 1994 and 1995. Final Report.

Hobart, B. 1999. "Globalization and its Impact on VET." Review of Research. Adelaide. NCVER.

Lane, J., and H. Tan. 1996. Evaluación del Programa DGETI. Processed.

Lee, K. W. 1998. "An Alternative Technical Education System: A Case of Study of Mexico.” International Journal of Educational Development. Oxford.

Lopez-Acevedo (2002). “A Reassessment of Technical Education in México.” Mimeo.

SEP (Secretaría de Educación Pública). 1997. Informe de Labores.

—. 1998. Informe de Labores. 1999a. Informe de Labores.

—. 1999b. Compendio Estadístico por Entidad Federativa.

OECD (Organisation for Economic Co-operation and Development). 1997. Reviews of National Policies for Education: Mexico Higher Education. Paris.

-2000. Education at a Glance. Paris. 
Power, C. 1999. "Technical and Vocational Education for the Twenty-First Century." Prospects: Quarterly Review of Comparative Education. Vol. XXIX. No. 1. pp. 29-36. Paris. UNESCO.

Sellin, B. 1999. European Trends in the Development of Occupations and Qualifications. Luxembourg. CDEFOP.

Smith, P. 1999. "The Internationalization of Vocational Education and Training." Review of Research. Adelaide. NCVER.

World Bank. 1997. "Mexico: Training Assessment Study.” White Cover Draft. 


\section{Annex}

Table A1.1. Cox Regression Model for Time to Find a Job After CONALEP

\begin{tabular}{|c|c|c|c|c|c|}
\hline \multirow[b]{2}{*}{ Variable } & \multirow[b]{2}{*}{$\begin{array}{c}\text { Hazard } \\
\text { Ratio }\end{array}$} & & \multirow[b]{2}{*}{ Std. Err. } & \multicolumn{2}{|c|}{ Confidence Interval } \\
\hline & & & & $L$ & $U$ \\
\hline 98 Survey & 1.45 & & 0.15 & 1.2 & 1.8 \\
\hline Women & 0.84 & & 0.03 & 0.8 & 0.9 \\
\hline Age & 0.99 & $*$ & 0.00 & 1.0 & 1.0 \\
\hline South-East Area & 1.22 & & 0.08 & 1.1 & 1.4 \\
\hline Center-South Area & 1.36 & & 0.08 & 1.2 & 1.5 \\
\hline North-East Area & 1.60 & & 0.09 & 1.4 & 1.8 \\
\hline North-West Area & 1.44 & & 0.08 & 1.3 & 1.6 \\
\hline Center-North Area & 1.45 & & 0.08 & 1.3 & 1.6 \\
\hline Pacific Area & 1.40 & & 0.08 & 1.3 & 1.6 \\
\hline 92 Cohort & 1.00 & $*$ & 0.11 & 0.8 & 1.2 \\
\hline 93 Cohort & 0.78 & & 0.10 & 0.6 & 1.0 \\
\hline 94 Cohort & 0.61 & & 0.12 & 0.4 & 0.9 \\
\hline 96 Cohort & 1.04 & $*$ & 0.09 & 0.9 & 1.2 \\
\hline 97 Cohort & 0.90 & $*$ & 0.18 & 0.6 & 1.3 \\
\hline Lower-secondary HH & 0.95 & $*$ & 0.04 & 0.9 & 1.0 \\
\hline Upper-secondary HH & 0.99 & $*$ & 0.06 & 0.9 & 1.1 \\
\hline University - + HH & 1.09 & $*$ & 0.10 & 0.9 & 1.3 \\
\hline Don't know HH & 1.00 & $*$ & 0.12 & 0.8 & 1.3 \\
\hline GDP per capita & 1.17 & & 0.07 & 1.0 & 1.3 \\
\hline $\begin{array}{l}\text { Did not work when } \\
\text { studying }\end{array}$ & 0.82 & & 0.03 & 0.8 & 0.9 \\
\hline No. of subjects $=$ & 40 & & & & \\
\hline No. of failures $=$ & 37 & & & & \\
\hline Log likelihood= & -28403 & & & & \\
\hline $\operatorname{LR} \operatorname{chi} 2(2)=$ & 294. & & & & \\
\hline Prob $>$ chi $2=$ & 0.0 & & & & \\
\hline
\end{tabular}


Table A1.2. Probability (Position in Occupation of CONALEP's Graduates). Marginal Effects Estimated.

\begin{tabular}{|c|c|c|c|c|c|c|c|}
\hline \multirow{2}{*}{ Variable } & \multicolumn{2}{|c|}{$\operatorname{Prob}[$ Position $=j \mid X$, dummy $=k]$} & \multirow{2}{*}{$\begin{array}{c}\text { Marginal } \\
\text { Effect }\end{array}$} & \multirow[b]{2}{*}{ Variable } & \multicolumn{2}{|c|}{$\operatorname{Prob}[$ Position $=j \mid X, d u m m y=k]$} & \multirow{2}{*}{$\begin{array}{l}\text { Marginal } \\
\text { Effect }\end{array}$} \\
\hline & $\begin{array}{c}\text { k=1 } \\
\text { Survey } 98\end{array}$ & $\begin{array}{c}\text { k=0 } \\
\text { Survey } 94\end{array}$ & & & $\begin{array}{c}\mathbf{k}=1 \\
\text { Survey } 98\end{array}$ & $\begin{array}{c}\text { k=0 } \\
\text { Survey } 94\end{array}$ & \\
\hline $\begin{array}{l}j=\text { Employer, self } \\
\text { employed }\end{array}$ & & & & $j=$ Employee & & & \\
\hline 98 Survey & 0.09 & 0.06 & 0.021 & 98 Survey & 0.893 & 0.903 & -0.010 \\
\hline Women & 0.06 & 0.09 & -0.029 & Women & 0.920 & 0.885 & 0.035 \\
\hline Age & & & 0.002 & Age & & & 0.001 \\
\hline South-East Area & 0.08 & 0.08 & -0.001 & South-East Area & 0.89 & 0.90 & -0.004 \\
\hline Center-South Area & 0.10 & 0.08 & 0.024 & Center-South Area & 0.87 & 0.90 & -0.029 \\
\hline North-East Area & 0.03 & 0.09 & -0.063 & North-East Area & 0.96 & 0.88 & 0.082 \\
\hline North-West Area & 0.05 & 0.09 & -0.035 & North-West Area & 0.94 & 0.89 & 0.049 \\
\hline Center-North Area & 0.08 & 0.08 & -0.006 & Center-North Area & 0.91 & 0.89 & 0.016 \\
\hline Pacific Area & 0.08 & 0.08 & -0.004 & Pacific Area & 0.90 & 0.89 & 0.009 \\
\hline Years after graduation & & & 0.010 & Years after graduation & & & -0.013 \\
\hline $\begin{array}{l}\text { Not working when } \\
\text { graduated }\end{array}$ & 0.07 & 0.10 & -0.037 & $\begin{array}{l}\text { Not working when } \\
\text { graduated }\end{array}$ & 0.91 & 0.87 & 0.047 \\
\hline Lower-secondary HH & 0.08 & 0.08 & -0.001 & Lower-secondary HH & 0.90 & 0.89 & 0.003 \\
\hline Upper-secondary HH & 0.09 & 0.08 & 0.005 & Upper-secondary HH & 0.88 & 0.90 & -0.020 \\
\hline University - + HH & 0.11 & 0.08 & 0.035 & University - + HH & 0.87 & 0.90 & -0.022 \\
\hline Don't know HH & 0.11 & 0.08 & 0.027 & Don't know HH & 0.88 & 0.89 & -0.015 \\
\hline GDP per capita & & & -0.001 & GDP per capita & & & 0.001 \\
\hline
\end{tabular}
Base categories for independent variables: 94 Survey, men, Center area (D.F .and Mexico), working when graduated from CONALEP, none or primary school education of household head (HH).
Units for GDP thousands of 1998 pesos. 
Table A1.2. cont.

\begin{tabular}{|c|c|c|c|c|c|c|c|}
\hline \multirow[b]{2}{*}{ Variable } & \multicolumn{2}{|c|}{$\begin{array}{c}\text { Prob }[\text { Position }=j \mid X, \\
d u m m y=k]\end{array}$} & \multirow{2}{*}{$\begin{array}{c}\text { Margina } \\
\text { l Effect }\end{array}$} & \multirow{2}{*}{ Variable } & \multicolumn{2}{|c|}{$\begin{array}{c}\operatorname{Prob}[\text { Position }=j \mid X, \\
d u m m y=k]\end{array}$} & \multirow{2}{*}{$\begin{array}{l}\text { Margina } \\
1 \text { Effect }\end{array}$} \\
\hline & $\begin{array}{c}k=1 \\
\text { Survey } 98\end{array}$ & $\begin{array}{c}k=0 \\
\text { Survey } 94\end{array}$ & & & $\begin{array}{c}k=1 \\
\text { Survey } 98\end{array}$ & $\begin{array}{c}k=0 \\
\text { Survey } 94\end{array}$ & \\
\hline $\begin{array}{l}j=\text { Cooperative's } \\
\text { member }\end{array}$ & & & & $\begin{array}{l}j=\text { Worker without } \\
\text { payment }\end{array}$ & & & \\
\hline 98 Survey & 0.00 & 0.01 & -0.009 & 98 Survey & 0.02 & 0.02 & -0.002 \\
\hline Women & 0.01 & 0.01 & -0.001 & Women & 0.01 & 0.02 & -0.006 \\
\hline Age & & & 0.000 & Age & & & -0.003 \\
\hline South-East Area & 0.01 & 0.01 & 0.003 & South-East Area & 0.02 & 0.02 & 0.002 \\
\hline Center-South Area & 0.01 & 0.01 & 0.002 & Center-South Area & 0.02 & 0.02 & 0.002 \\
\hline North-East Area & 0.00 & 0.01 & -0.007 & North-East Area & 0.01 & 0.02 & -0.011 \\
\hline North-West Area & 0.00 & 0.01 & -0.004 & North-West Area & 0.01 & 0.02 & -0.011 \\
\hline Center-North Area & 0.00 & 0.01 & -0.006 & Center-North Area & 0.01 & 0.02 & -0.004 \\
\hline Pacific Area & 0.01 & 0.01 & 0.000 & Pacific Area & 0.01 & 0.02 & -0.005 \\
\hline Years after graduation & & & 0.000 & Years after graduation & & & 0.003 \\
\hline $\begin{array}{l}\text { Not working when } \\
\text { graduated }\end{array}$ & 0.01 & 0.01 & -0.002 & $\begin{array}{l}\text { Not working when } \\
\text { graduated }\end{array}$ & 0.01 & 0.02 & -0.008 \\
\hline Lower-secondary HH & 0.00 & 0.01 & -0.003 & Lower-secondary $\mathrm{HH}$ & 0.02 & 0.02 & 0.001 \\
\hline Upper-secondary HH & 0.01 & 0.01 & 0.003 & Upper-secondary HH & 0.03 & 0.02 & 0.012 \\
\hline University - + HH & 0.00 & 0.01 & -0.007 & University - + HH & 0.01 & 0.02 & -0.006 \\
\hline Don't know HH & 0.00 & 0.01 & -0.007 & Don't know HH & 0.01 & 0.02 & -0.006 \\
\hline GDP per capita & & & -0.001 & GDP per capita & & & 0.000 \\
\hline
\end{tabular}


Table A1.3. Regression Estimated Coefficients. Dependent Variable: Log(Earnings per hour)

\begin{tabular}{|c|c|c|c|c|c|c|c|}
\hline \multirow[b]{2}{*}{ Variable } & \multirow[b]{2}{*}{ Coefficient } & & \multirow[b]{2}{*}{ Std. Err. } & \multirow[b]{2}{*}{$T$} & \multirow[b]{2}{*}{$P>|t|$} & \multicolumn{2}{|c|}{ Confidence Interval } \\
\hline & & & & & & $L$ & $U$ \\
\hline 98 Survey & -0.29 & & 0.024 & -11.9 & 0.00 & -0.34 & -0.24 \\
\hline Women & -0.10 & & 0.019 & -5.4 & 0.00 & -0.14 & -0.07 \\
\hline Age & 0.01 & & 0.002 & 6.3 & 0.00 & 0.01 & 0.02 \\
\hline South-East Area & -0.20 & & 0.034 & -5.9 & 0.00 & -0.26 & -0.13 \\
\hline Center-South Area & -0.08 & & 0.031 & -2.7 & 0.01 & -0.14 & -0.02 \\
\hline North-East Area & -0.04 & * & 0.029 & -1.4 & 0.17 & -0.10 & 0.02 \\
\hline North-West Area & -0.03 & * & 0.030 & -0.9 & 0.36 & -0.09 & 0.03 \\
\hline Center-North Area & -0.09 & & 0.028 & -3.2 & 0.00 & -0.14 & -0.03 \\
\hline Pacific Area & -0.05 & & 0.029 & -1.7 & 0.09 & -0.10 & 0.01 \\
\hline Years after graduation & 0.07 & * & 0.043 & 1.6 & 0.12 & -0.02 & 0.15 \\
\hline Years after graduation`2 & 0.00 & * & 0.007 & -0.5 & 0.62 & -0.02 & 0.01 \\
\hline Lower-secondary HH & 0.09 & & 0.020 & 4.3 & 0.00 & 0.05 & 0.13 \\
\hline Upper-secondary HH & 0.11 & & 0.037 & 3.0 & 0.00 & 0.04 & 0.19 \\
\hline University - + HH & 0.15 & & 0.045 & 3.5 & 0.00 & 0.07 & 0.24 \\
\hline Don't know HH & -0.02 & * & 0.060 & -0.3 & 0.77 & -0.14 & 0.10 \\
\hline GDP per capita & -1.00 & & 0.368 & -2.7 & 0.01 & -1.72 & -0.28 \\
\hline $\begin{array}{l}\text { Did not work when } \\
\text { studying }\end{array}$ & -0.10 & & 0.018 & -5.5 & 0.00 & -0.13 & -0.06 \\
\hline Employee & -0.24 & & 0.032 & -7.4 & 0.00 & -0.30 & -0.18 \\
\hline Cooperative's member & 0.04 & * & 0.111 & 0.4 & 0.69 & -0.17 & 0.26 \\
\hline Worker without payment & -0.83 & & 0.109 & -7.6 & 0.00 & -1.04 & -0.61 \\
\hline Agriculture, fishing & -0.28 & & 0.068 & -4.1 & 0.00 & -0.41 & -0.14 \\
\hline Construction & -0.09 & & 0.055 & -1.7 & 0.10 & -0.20 & 0.02 \\
\hline $\begin{array}{l}\text { Commerce, rest., and } \\
\text { hotels }\end{array}$ & -0.22 & & 0.023 & -9.6 & 0.00 & -0.26 & -0.18 \\
\hline Other activity sectors & -0.06 & & 0.020 & -2.7 & 0.01 & -0.10 & -0.02 \\
\hline Constant & 6.19 & & 1.391 & 4.5 & 0.00 & 3.47 & 8.92 \\
\hline Number of observations & 4534 & & & & & & \\
\hline $\mathrm{F}(25,4508)$ & 26.96 & & & & & & \\
\hline Prob $>F$ & 0.00 & & & & & & \\
\hline $\mathrm{R}^{2}$ & 0.13 & & & & & & \\
\hline Adjusted $\mathrm{R}^{2}$ & 0.12 & & & & & & \\
\hline
\end{tabular}

